\title{
Результаты селекции картофеля в Кемеровском НИИСХ - филиале СФНЦА РАН
}

\author{
А.Н. Гантимурова*, В.И. Куликова, В.П. Ходаева, Н.А. Лапшинов \\ Кемеровский научно-исследовательский институт сельского хозяйства - филиал \\ Сибирского федерального научного ичентра агробиотехнологий РАН, пос. Новостройка, \\ Кемеровская область, Россия \\ *e-mail: anna_gantimurova@mail.ru
}

В Кемеровском научно-исследовательском институте сельского хозяйства ежегодно изучается исходный материал картофеля с последующим отбором лучших форм и использованием его в селекционном процессе. Генетические источники выделяются по признаку урожайности, раннеспелости, содержанию крахмала, устойчивости к основным болезням, адаптивным свойствам, пригодности к переработке. На основе полученных данных создан ряд перспективных гибридов, сочетающих в себе ценные признаки. При создании сортов картофеля одним из важных показателей хозяйственно ценных признаков является их продуктивность. В 2016-2017 гг. выделены гибриды с урожайностью 681-775 г/куст: 4-5-14, 6-1-14, 22103-10, 17-5/6-11, 11-13, 159-1, 3-24-14, 1-1-14, 175-10, достоверно превышающие стандартный сорт Невский на 61-378 г/куст при $\mathrm{HCP}_{05}$ 52,96. Крахмалонакопление в клубнях картофеля является качественным признаком, который определяет назначение сорта на вид переработки (спирт, крахмал). Выделены образцы с высоким содержанием крахмала (18 \% и более): 5-20c-12 (21,8 \%), 12-7c-11 (21,3 \%), 141-13 (21,25 \%), 9-14-12 (21,17\%), 81-13 (20,1\%), 8-10-12 (18,83 \%). Для получения качественной продукции необходимы сорта с хорошими вкусовыми качествами, способные сохранить цвет мякоти в процессе изготовления картофелепродуктов, выделены гибриды 82-13, 1-1-14, 12-7c-11. Устойчивость к вредителям и болезням у картофеля обеспечивается доминантными генами, которые способны оказывать свое действие даже в симплексном состоянии и защищают растение. ДНК-маркеры, тесно сцепленные с генами устойчивости, значительно ускоряют поиск селекционно-ценных образцов. Исследования проведены в ООО «Синтол» (Москва) на клубневом материале картофеля Кемеровского НИИСХ - филиала СФНЦА РАН по выявлению маркеров генов устойчивости. Выделены гибриды картофеля, имеющие гены устойчивости к патогенам $Y$-вирусу (Rysto) - 11-13, 9-14-12, 1/5-3-13, 1-1-14, 3-21c-11, 22103-10, 1-5-12 и (Rychc) - 17-5/6-11, 1-5-12; $X$-вирусу $(P V X)-81-13,1-1-14 ;$ золотистой картофельной нематоде (Globodera rostochiensis) (H1) - 141-13, 11-13, 8-10-12, 9-14-12, 1/5-3-13, 1-1-14, 5-11-14, 14-129-08, 17-5/6-11, 3-21 с-11, 22103-10, 6-14-11, 1-5-12 и (Grol-4) - 1-5-12, 3-21с-11, 22103-10; бледной картофельной нематоде (Globodera pallida) (Gpa 2) - 1-5-12, 81-13; раку картофеля (Synchytrium endobioticum) (NL 25) - 8-10-12, 1-1-14, 4-5-14, 5-11-14. По результатам анализа полимеразной цепной реакции (ПЦР-анализ) с комплексом генов устойчивости к патогенам выделены гибриды 1-5-12, 3-21c-11, 22103-10, 1-1-14.

Благодарности: Исследования проведены в рамках Федеральной научно-практической программы развития сельского хозяйства на 2016-2025 гг. по приорететному направлению «Картофелеводство» и Федеральной программы по биоресурсной коллекции «Сорта и гибриды картофеля, селекционные исследования» Кемеровского НИИСХ - филиала СФНЦА РАН. 